\title{
Çocuklarda Adalet Bilinci ve Ekonomik Koşulların Adalet Bilinci Üzerine Etkisi ${ }^{a}$
}

\author{
Özge Ayan ${ }^{b}$, Burcu Gediz Oral c, d, Tuğba Arpazlı Fazlılare
}

Özet

Anahtar Kelimeler

Adalet duygusu büyüme sürecinde çocukların bulunduğu çevreye göre bir Adalet noktaya kadar kendiliğinden gelişmektedir. Bu gelişim sürecinde ilköğretim dönemi, çevresel unsurlar ve sosyalleşme ile çocuğun pek çok konuda davranış temellerinin oturduğu bir dönemdir. Bu bağlamda; çalışmanın temel amacı çocuklardaki adalet duygusunun gelişimini ve adaletsizliğe verdikleri tepkiyi gözlemlemek, ekonomik refah düzeyi ve adalet bilinci arasındaki ilişkiyi ortaya koymaktır. Literatür konunun çocukluk çağında nasıl şekillendiği hususunda oldukça sınırlıdır. Çalışmanın sonuçları bu konuda literatüre katkı sağlama açısından önem taşımaktadır. Analiz sonuçlarına göre; ilköğretim çağındaki çocukların adaletsizliğe karşı tepki göstermeleri ile sahip oldukları kardeş sayısı arasında güçlü ancak zıt yönlü bir ilişki vardır. Yani kardeş sayısı arttıkça verilen tepki azalmaktadır. Buna ek olarak ebeveynlerin medeni durumlarının da çocukların verdikleri tepkiler ile ilişkili olduğu görülmüştür. Diğer değişkenler oldukça zayıf ilişki sergilemişlerdir. Dolayısıyla ilköğretim çağındaki çocukların adaletsizliğe verdikleri tepkilerin, ekonomik koşullardan değil içinde büyüdükleri sosyal ortamdan etkilendiği sonucuna ulaşılmıştır.

\section{Justice Awareness in Children ve the Effect of Economic Conditions on Justice Consciousness}

\begin{abstract}
The sense of justice is developing to a point spontaneously in this growth process according to the environment of the children. The primary education period in this development process is a period of the foundation of the behavior of child's in many issues with environmental factors and socialization. The literature is very limited as to how the subject took shape in childhood. Although there are studies on the subject, studies on how the subject is shaped in childhood are quite limited. The results of this study are important in terms of contributing to the literature. According to the analysis results, there is a strong but opposite relationship between showing reaction to the injustice and the number of siblings they have. In other words, as the number of siblings increases, their action decreases. In addition, it was observed that the marital status of the parents was also related to the actions of the children. Other variables showed a very weak relationship. Therefore, it has been concluded that the reactions of primary school children to injustice are not affected by economic conditions but by the social environment in which they grow up.
\end{abstract}

Keywords

Justice,

Justice Awareness,

Economy

Economic Conditions

About Article

Received: 01.02.2021

Accepted: 21.06.2021

Doi: 10.18026/cbayarsos. 872286

\footnotetext{
a Bu çalışma, Manisa Celal Bayar Üniversitesi Bilimsel Araştırma Projeleri Koordinasyon Birimi tarafından desteklenen 2019-010 nolu "İlköğretim Çağındaki Çocuklarda Adalet Bilinci ve Ekonomik Koşulların Adalet Bilinci Üzerindeki Etkisi: Manisa İli Örneği” adlı proje çalışmasından türetilmiştir. Desteklerinden dolayı Bilimsel Araştırma Projeleri Koordinasyon Birimi'ne teşekkür ederiz.

b Doç. Dr., Manisa Celal Bayar Üniversitesi, Uygulamalı Bilimler Fakültesi, Şehit Prof. Dr. İlhan Varank Yerleşkesi, ORCID: 0000-0002-2612-6846.

c İletişim Yazarı: burcu.gediz@cbu.edu.tr

d Doç. Dr., Manisa Celal Bayar Üniversitesi, Uygulamalı Bilimler Fakültesi, Şehit Prof. Dr. İlhan Varank Yerleşkesi, ORCID: 0000-0001-7096-9288.

e Araş. Gör. Dr., Manisa Celal Bayar Üniversitesi, Uygulamalı Bilimler Fakültesi, Şehit Prof. Dr. İlhan Varank Yerleşkesi, ORCID: 0000-0001-8838-8959.
} 


\section{Giriş}

Adalet kavramı insanoğlunun bilinciyle var olduğundan bu yana üzerinde düşünülen, felsefe temeline oturtularak tartışılan, kamu vicdanında karşılık bulan ve bunun sonucu olarak da tüm toplumlarda dönem ve anlayış çerçevesinde kurulu hukuk düzeninin kaynağını oluşturan bir kavramdır.

Eski çağlardan günümüze adalet kavramının ortaya çıkışı pek çok düşünür tarafından ele alınmış bir konudur. Kant, adaleti yasalarla sınırlandırılmış bir kavram olarak ele almış olsa da bu konudaki genel görüş, adaletin bir duygu olarak insan vicdanından doğduğudur. Dolayısıyla insanın bu duyguyu fark etme, anlamlandırma ve kendisinde geliştirerek davranışlarına yansıtma gibi aşamaları olacaktır. Bu düşünceden yola çıkarak özellikle çocukluk çağında bu duygunun davranışlara yansımalarının ne zaman ve nasıl ortaya çıktığına dair çalışmalar literatürde yer almaya başlamıştır. Çalışmalar henüz sınırlı da olsa ortak noktaları, adalet duygusunun çocukluk çağında ilkel basamaktan başlayarak evrildiğidir. Burada ilkel basamak olarak ifade ettiğimiz nokta; çocukların önce kendilerine yapılan adaletsizliğe karşı çıkmaya başlamaları olup ilerleyen dönemlerde başkalarına yapılan haksızlı̆̆a da tepki verme aşamasına geçmeleridir. Ancak bu aşamaların gelişiminde ve davranışlara yansımalarında çocukların yetişme koşullarının etkileri de görülmektedir. Bu alanda literatürde deneysel gözlem içeren çalışmalar yapılmakla birlikte yerli literatürde henüz bu içerikte bir çalışmaya rastlanmamaktadır.

Sahip olduklarını paylaşmak bireylere bir maliyet getirir ve kişisel çıkar sıklıkla bu özgecil davranışı baskın hale getirir veya kısıtlar. Çocuklar büyüdükçe elindekileri paylaşmaya daha istekli hale gelirler. Ancak bu gelişimsel değişimin altında yatan mekanizma belirsizdir. Bu konuyu ele alan araştırmalarda çocukların paylaşıma dayalı eylemlerinin toplumsal kültürden etkilendiğini ortaya koyan sonuçlar bulunmaktadır. Bu çalışmalar çocukların paylaşma normlarını içinde büyüdükleri toplumda, büyükleri taklit ederek öğrendiklerini bu nedenle kültüre göre sonuçların farklılık gösterebileceğini öne sürmektedir.

Dolayısıyla bu türde bir deneysel gözleme dayalı çalışma yapmamızın temelini bu nokta oluşturmuştur. Uygulama için ilköğretim çağındaki çocuklar seçilmiş ve çalışma alanı Manisa İli ile sınırlandırılmıştır. Çalışmamızda seçili örneklemde yalnızca adalet duygusunun nasıl bir gelişim gösterdiği değil, bu duygunun verilen tepkilere yansımasında hangi faktörlerin etken olabileceği de araştırılmıştır. Bunun için kardeş sayısı, anne ve babanın eğitim düzeyleri ve medeni durumları, gelir düzeyi, ev sahibi olup olmama değişkenleri de araştırmaya dahil edilerek çocukların adalet anlayışlarında bu faktörlerin etkisinin olup olmadiğ korelasyon testi ile analiz edilmiştir.

Çalışma iki temel amaca dayanmaktadır. Bunlardan birincisi; çocuklarda adalet bilincinin mevcut durumunun tespitidir. Diğeri ise çocukların içinde bulundukları sosyo-ekonomik koşulların adalet duygularını etkileyip etkilemediği konusunda bir fikir oluşturmaktır. Çalışmanın temel amaçlarına uygun olarak belirlenen hedefler ve izlenecek yönteme göre; teorik bölüm literatür taraması ile birlikte oluşturulmuştur. Uygulama bölümü ise aşağıda belirtilen üç ana aşamadan oluşmaktadır: (1) Belirlenmiş örneklem grubu için, bir uzman (psikolog) gözetiminde, çocukların adalet duygularını gözlemlemeye yönelik deneysel bir etkinlik düzenlenmiş ve sonuçlar kayıt altına alınmıştır. (2) Deneye katılan çocukların ailelerinin gelir düzeyleri ve sosyal statülerine ilişkin bilgiler derlenmiştir. (3) Elde edilen veriler uygun veri analiz yönteminde bir araya getirilerek analiz edilmiştir. 


\section{Adalet Kavramının Felsefi Temelleri}

Tarih boyunca çok az soru, "Adalet ve hukuk nedir?" sorusu kadar incelenmiş ve farklı alanlardan ele alınan çok sayıda yanıt üretmiştir. Adalet kavramı, geçmişten günümüze tüm hukuk sistemlerinin temelini ve gerekçesini oluşturan kaynak olarak karşımıza çıkmaktadır. Adaletin felsefi temelleri, kavramın belirgin olarak ele alındı̆̆ı eski Yunan Felsefesine dayanmaktadır. Bu dönemde adalet genellikle insana ait bir erdem olarak değerlendirilmiştir. Ancak; sistematik olarak kavramı ilk ele alan grup Sofistler olmuştur. Sofistler, genel olarak adalet kavramının olmadığını öne sürmüsslerdir. Bunun gerekçesi ise herkesin kendi bakış açısından "doğru” yu görmesi ve tek bir doğrunun olmaması temel görüşüne dayalı olarak, adaletin de egemen gücün çıarlarına göre sağlanmaya çalışılacağı düşüncesidir. Bazı Sofistler ise adaletin güç kavramı ile ilişkili olduğunu, gücü elinde tutan çıkar gruplarının kendilerine göre bir adaleti savunacaklarını ve dayatacaklarını öne sürmüşlerdir. Diğer bir grup Sofist ise bu görüşe zit görünen bir başka görüş öne sürmüştür. Bunlara göre; bir toplumdaki zayıf taraf adalet kavramının altına sığınarak kendi çıkarları doğrultusunda bir hukuk sistemi kurulması yönünde baskı yaparak kendilerince bir denge kurmaya çalışmışlardır (Çeçen, 2020, s. 101102).

Sokrates Sofistlere karşı çıkarak adaleti yalnızca bir değer, bir erdem olarak savunmuştur. Sokrates'e göre ulaşılabilecek evrensel bir doğru vardır. Hukuk sistemi içerisinde ve politikada adaleti ve ahlakı hâkim kılmak Sokrates'in temel ideallerinden biri olmuştur. Ancak adaletin var olabilmesi için toplumu akıllı ve ahlaklı erdem sahibi insanların yönetmesi gerekmektedir. Bununla birlikte Sokrates'e göre adalet, iyi olanı kötü olandan ayırma bilgisidir ve bu kişilerin vicdanında beliren bir duygudur (Çeçen, 2020, s. 105).

Sokrates'in yetiştirdiği Platon (M.Ö.427-347), kendi döneminde adalet kavramından en çok bahseden ve konuya en geniş yer veren filozof olarak betimlenmektedir. Platon da Sokrates gibi adalet kavramını temelde insan vicdanının sesi olarak ele alır. Dolayısıyla birey için adaletin iç dünyası ile ilişkili olduğunu, insanın adil olmasının iç dünyasını düzene sokup dengeli bir hal almasını sağlayacağını öne sürer. Platon'a göre bireyin adil davranışı, akıllı, zeki, bilge, ölçülü ve cesur olmasından kaynaklanır. Bununla birlikte Platon için adalet kişisel olduğu kadar toplumsal bir erdem olmalıdır. Aksi takdirde gerçekleşmesi mümkün olmayacaktır. Toplumsal bir erdem olan adalet devlette karşılığını bulacaktır. Ancak Platon bunun, insanlara politik düzende iyi bir eğitimle erdemlerin öğretilmesi yoluyla mümkün olabileceğini, bu nedenle de devleti böyle bir eğitimden geçmiş filozofların yönetmesi gerektiğini söylemektedir (Demirtaş, 2016).

Aristo (M.Ö 385-322) adaleti en yüksek erdem olarak ele almıştır. Evrensel adaleti etik kuramın temel öğretilerinden biri kabul eden Aristo, bireysel adaleti ise eşitlik kavramı ile özdeşleştirmiştir. Ancak buradaki eşitlik kavramı mutlak bir eşitlik değildir. Yani her bireye yetenek, onur ve toplumsal statü gözetilmeden eşit davranılması eşitlik ilkesine ters düşecek dolayısıyla adil olmayacaktır. Bu açıdan bakıldığında Aristo'nun adalet anlayışı yasaları aşan bir özellik taşımaktadır. Çünkü adalet insanda sevgi duygusuyla birlikte ortaya çıkmaktadır. Dolayısıyla toplumsal anlamda mutluluk ancak adaletli bir ortamın oluşturulabilmesi ile mümkündür (Çeçen, 2020).

İslam filozoflarından Farabi'ye (872-950) göre ise, adalet duygusu diğer ahlaki duygularla birlikte kişide potansiyel olarak bulunur. Ancak bu erdemlerin üzerine eğilerek geliştirmek, şekillendirmek gereklidir. Platon ve Aristo gibi Farabi de adaletin hem bireyde hem toplumda olması gerektiği görüşündedir. Bunun için devlet adamları erdemli kişiler olmalıdır. Farabi'nin adalet anlayışında da sevgi temel olarak yer almaktadır. Farabi'ye göre sevgi ile 
kurulan ve yönetilen bir devlet adil olarak yönetilerek devam eder. Farabi diğer bütün etik değerlerin adalet değerine bağlı olarak var olduğunu ancak adaletin tek başına bağımsız bir değer olduğunu öne sürer (Demirtaş, 2016).

Genel olarak felsefenin temelinde adalet kavramı geniş yer bulmakta ve Machiavelli, Hobbes, Locke, Rousseau, Smith, Montesquieu, Voltaire gibi 17.-18. yy. filozofları tarafından temel bir erdem olarak insanla ilişkilendirilerek hukuk sisteminin oluşturulmasında oynadığı rol vurgulanmaktadır. Bu bağlamda adaletin insan doğasında gelişen vicdani bir duygu olduğu söylenebilir. Eski Yunan felsefesinden günümüzde tartışılagelen konularda Aristo ve Kant karşılaştırmalarına sıklıkla rastlanmaktadır. Ancak Kant'ın adalet konusuna bakışı görece dar bir çerçeve ile sınırlı kalmaktadır. Çünkü Kant adaleti yasalarla ve/veya hukuk sistemi ile sınırlı tutmuştur. Kant, yasaların emrettiği şeyin adil olduğunu öne sürerken pek çok felsefeci için konuyu son derece daraltmış ve tartışmalı hale getirmiştir (Campbell, 1988).

Felsefi düşüncede günümüze yaklaşırsak, Hans Kelsen (1881-1973), doğal hukuk doktrinini, iyilik ve adalet fikrinin kesin ifadesi açısından tatmin edici bir dizi insan davranış kuralını, insan doğasından yola çıkarak oluşturma girişimi olarak karakterize eder. Ek olarak, doğa hukuku doktrini, pozitif hukuk ve doğa hukuku arasındaki ikilikten başlar. "İnsan tarafından yaratılan kusurlu pozitif yasanın üzerinde, ilahi bir otorite tarafından kurulmuş (ve kesinlikle adil) mükemmel bir doğal yasa vardır. Bu nedenle, pozitif yasa haklıdır ve doğal hukuka karşılık geldiği ölçüde geçerlidir (Esteban, 2005).

Hart (2012) göre ise hukukçuların çoğunlukla "iyi" ve "kötü" demek yerine "adil/adil değil" kavramlarını kullanırlar. Bu da hukuk camiasında egemen görüşün, adalet fikrinin çeşitli uygulamalarında saklı olan genel ilkenin bireylerin kendi aralarında belirli bir görece eşitlik veya eşitsizlik konumuna sahip olması yönünde olduğunun göstergesi olarak kabul edilebilir. $\mathrm{Bu}$ ilkeye göre, gerekli olduğunda, sosyal yaşamın dengelerine saygı gösterilmesi gerekir. Bu açıdan bakıldığında adalet ile bir kurala göre işlem yapma fikri arasındaki bağlantı açıkça çok yakındır. Bir hukuki kuralı farklı davalara adil bir şekilde uygulamanın, farklı durumlarda uygulanması gereken şeyin önyargı, ilgi veya heves olmaksızın aynı genel kural olduğu ifadesini ciddiye almak olduğu söylenebilir (Hart, 2012).

Rawls (1973), adalet sorununu hukuk felsefesinden ziyade siyasal ve sosyal bir felsefe perspektifinden analiz etmiştir. Bu bağlamda Rawls, adaletin rolünün sosyal kurumların birinci erdemi olduğunu belirtir ve haksılıklar önlenmedikçe yasaların ve kurumların düzenli ve verimli olmalarının bir önemi olmadığını vurgular. Rawls, adalet teorisini Locke, Rousseau ve Kant'a kadar uzanan sosyal sözleşme teorisi geleneğine yerleştirir. Dolayısıyla düşünür için adalet yalnızca yasalar çerçevesinde ele alınmış bir kavramdır (Rawls, 1973).

Dworkin (1986) ise adaleti her bir bireyin içinden gelen ve şekillenen ahlaki bir duygu olarak ele almıştır. Bu yönüyle Dworkin'in görüşü, bizim çalışmamız da dahil olmak üzere bu duygunun şekillenmesini konu alan çalışmaların temelinde önemli bir yer tutar. Ancak Dworkin'e göre adalet, etik duygular içerisinde en politik olanıdır. Dolayısıyla sosyal düzen uygulamalarında geniş yer tutar. Rawls'ın cinsiyet ayrımcılığına dayanan görüşünü de ciddi anlamda eleştiren Dworkin, kadın ve erkeklerin doğal olarak eşit ilgi ve saygıyı hak ettiklerini özellikle vurgular. Adalet dağıtıcı da bu durumu dikkate almalı ve sağlamalıdır (Dworkin, 1986).

\section{Literatür}

Felsefi düşünce temelinde adalet kavramı, devletin yönetimi ile ilişkili olarak ele alınmışsa da geçmişten günümüze düşünürlerin birey için vurguladığı adalet duygusu vicdanda varlık göstermektedir. Bu bağlamda bireyle birlikte etik duygunun gelişimi, bireyin farkındalık 
düzeyi çerçevesinde gelişecek ve çeşitli faktörlerle şekillenecektir. Teorik anlamda konuyu inceleyen temel çalışmalardan biri olan Kristja'nsson (2004), çocukların ahlakının kaynağı olarak gösterilen doğal empati teorisini incelediği makalesinde, adaletin çocuğun orijinal empati kapasitesine dayandığını belirtmektedir. Çalışma duygusal bir erdem olarak "adalet" $i$ içselleştirme modellerini de özetlemektedir. Buna göre; (i) Sosyal Öğrenme Teorileri çocukların ahlaki bilişlerinin ve eğilimlerinin sosyal öğrenmeden, yani çocukların diğer sosyal temsilcilerle olan deneyimlerinden kaynaklandığını ve güçlendirme ve modelleme / gözlem yoluyla kademeli olarak şekillendiğini iddia etmektedir. (ii) Ekonomik teoriler dayanaklarını, başkalarıyla etkileşimde bulunurken büyük ölçüde kişisel çıkarla motive edilen, ancak biçimci rasyonalitesinden dolayı kademeli olarak bir ahlaki sistemi kodlayan Homo-ekonomikus fikrinden almaktadır. Ancak özellikle adil dünya teorisyenleri, ekonomik teorilerin adaleti içselleştirmeye özellikle uygun olmadığını iddia etmektedirler. Çünkü onlara göre, çocukluktan itibaren genel olarak bakıldığında insanlar, normalde adaleti ikincil bir kaynak, "karşılıklı menfaatler" gibi diğer daha temel kaynakların elde edilmesini kolaylaştıran araçsal bir kavram olarak değil, tek başına bağımsız bir değer olarak düşünür. Dahası, ekonomik teoriler, biçimsel, rasyonel süreçlere ağırlık verdikleri için, duyguların adaletin içselleştirilmesindeki rolü konusunda oldukça belirsiz olma eğilimindedir. (iii) Biyolojik teoriler, adaleti içselleştirmenin biyolojik temellerini primatlar düzeyinde başlattıkları deneysel gözlemlerle araştıran çalışmalar ortaya koyarlar. Bu çalışmaların büyük kısmı primatlardan itibaren bir adalet duygusunun gözlemlenebildiğini ortaya koysa da ahlaki eleştiriler getiren çevreler tarafından bu çalışmalar ağır eleştirilere maruz kalmıştır. (iv) Psikolojik teoriler oldukça eskiye dayanmakla birlikte saf psikanalitik teoriler artık eskisi kadar öne çıkmamaktadırlar. Ancak son zamanlarda revaçta olan adil dünya teorisi Freudcu Psikanaliz, Gestalt Psikolojisi ve Mead'in Sembolik Etkileşimciliği'nden etkilenmiştir. Bu teoriye göre, insanlar temel, ilkel bir "adalet güdüsüne" sahiptir: psikolojik olarak neredeyse evrensel, duygusal olarak yönlendirilen çocukluk farkındalığına dayanan bir dürtü, arzuların anlık tatmininin uzun vadeli kazanç lehine ertelenebileceğini ve geciktirilmesi gerektiği duygusunu oluşturur. Adil dünya teorisi adalet ve duygular arasındaki ilişkide güçlüyken hem bireysel hem de toplumsal farklılıkları "adalet saikinin" gücüyle açılamakta yetersiz kalmaktadır (Kristia'nsson, 2004).

Çocuklardaki adalet duygusunun gelişimi ve hangi faktörlerden etkilendiği konusunda yapılan deneysel çalışmalara ilişkin literatüre bakıldığında, çocuklarda adalet bilincinin araştırılmasına ilişkin temel çalışmalardan biri, Blake ve McAuliffe (2011) tarafindan yayınlanmıştır. Çalışmada Boston ve çevresindeki kasabalarda yaşayan 178 kişilik örneklem grubu ile deneysel bir oyun oynanmış ve çocukların adalet duygularının nasıl işlediği gözlemlenmiştir. Kurulan oyun düzeneğinde bir yetişkin tarafından çocukların önüne şekerler bırakılmış, karşılıklı oturan iki çocuktan biri karar verici olarak belirlenmiştir. Eşitsizlik Oyunu adını verdikleri oyunda çocuklar, tanımadıkları bir akranla eşleştirilmiş ve ebeveynleri izlerken oyunu oynamışlardır. Mevcut deney, çocuklarda eşitsizlikten kaçınma hakkındaki literatüre üç katkı sağlamaktadır. İlk olarak, tanıdık bir akranla eşleştirildiğinde çocuklar avantajlı eşitsizliği reddetmektedirler. 8 yaşına gelindiğinde, çocuklar bir akranının onlardan daha az almasını önlemek için büyük bir göreceli ödülü (dört şeker) reddetmiştir. İkinci olarak, aynı yöntemi kullanarak sınanan durumda çocuklar iki eşitsizlikten kaçınma biçimi için farklı gelişimsel seviyeler göstermektedir. Her yaştan çocuklar, yaşla birlikte artan bir eğilimde dezavantajlı teklifleri reddetmiştir. Özellikle dezavantajlı eşitsizliğe maruz kalan 8 yaşından küçük çocuklar, bir akranının dört şeker almasını önlemek için bir şekeri feda etmeye istekli 
görülmüşlerdir. Buna karşılık, 8 yaş ve üzerindeki çocuklar hem dezavantajlı hem de avantajlı eşitsizliği reddetmiştir. Üçüncü olarak, bu çalışma eşitsizlikten kaçınma görevinde olan çocuklar için ilk reaksiyon süresi ölçümlerini de sunmaktadır. Reaksiyon süresi analizleri Eşitsizlik Oyununda koşullar arasında daha fazla farklılık olduğunu ortaya koymaktadır. Dezavantajlı durumda, dezavantajlı teklifi nihai olarak kabul etmeleri ya da reddetmeleri daha uzun sürmüştür. Avantajlı durumda, reaksiyon süresi verileri 8 yaşından küçük çocuklar için hem avantajlı hem de adil durumlara karar vermek için aynı miktarda zaman harcamış, ancak avantajlı bir teklifi reddetmek, kabul etmekten daha yavaş olmuştur. Sonuç olarak, küçük çocukların aksine, 8 yaşındaki çocuklar avantajlı bir teklifi kabul etseler bile, bunu yapmadan önce tereddüt etmişlerdir (Blake ve McAuliffe, 2011).

Olumlu bir teklifin reddedilmesi, birçok ekonomik insan davranışı modelinde mantıksız kabul edilir. Bununla birlikte, sosyal ortamlarda eşitsizliğin reddedilmesi daha büyük bir amaca hizmet edebilir. Dezavantajlı teklifleri reddedenler kötü bir anlaşmayı kabul etmeyeceklerini gösterebilirken, avantajlı bir teklifi reddedenler kişisel kazançların üzerinde adalete değer verdiklerini gösterebilirler. Her iki tür düşünmede kişinin eylemlerinin, diğerleri gözündeki itibarına katkıda bulunduğunun farkındalığını gerektirir. Buna göre çalışmanın sonuçları göstermektedir ki çocuklar için, bir itibar ya da kendini sunma kaygısı 6-8 yaş arasında gelişmektedir. Bu nedenle, Eşitsizlik Oyunu'nda, itibar kaygıları büyük çocukların neden bazı teklifleri reddettiğini açıklamaya yardımcı olabilir. Örneğin, çocuklar ebeveynlerine veya diğer çocuklara adil oldukları konusunda mesaj vermek için avantajlı teklifleri reddedebilirler (Blake ve McAuliffe, 2011, s. 222).

Benzer konuda Benenson vd. (2007), 4-9 yaş aralığındaki çocukların alturistik (fedakârlık) davranışlarını incelerken, 360 çocuğu örneklem olarak seçmişler ve ailelerin sosyo-ekonomik durumlarını da çalışmalarına dahil etmişlerdir. Söz konusu çalışmada diktatör adlı ekonomi oyunu çocuklara uyarlanarak kullanılmakla birlikte beyin görüntüleme tekniklerinden de yararlanılmıştır. Çalışmada daha iyi sosyo-ekonomik durumdaki ailelerin çocuklarının fedakârlığa daha eğilimli olduğu sonucuna varmışlardır. Yani Benenson vd. (2007)’ye göre; çocukların davranışsal gelişimleri sosyo-ekonomik açıdan kalkınmışlık düzeyi ile etkileşim içindedir. Ancak burada araştırılan konu çocukların sadece adalet duyguları değil, genel olarak alturistik davranışları ve bu davranış biçimlerinin sosyoekonomik durum ile ilişkisi olmuştur (Benenson vd., 2007).

Murnighan ve Saxon (1998), “Ultimatom Oyunu (UG)” adlı pazarlık oyunu kullanarak benzer bir çalışma yapmışlardır. Çalışmanın ana teması; pazarlık gücünün adil davranış biçimini nasıl şekillendireceğidir. Oyun hem yetişkinlere hem çocuklara uygulanmış ve sonuçlar bu sınıflandırmaya göre değerlendirilmiştir. Ulaşılan sonuç önceki çalışmalardakilere benzer şekilde 8 yaş üstünün daha adil bir tutum sergilediği, bununla birlikte her durumda pazarlık yapılan miktarın ne kadar olduğu bilinmiyorsa karar vericilerin daha küçük miktardaki teklifleri kabul etmeye eğilimli oldukları yönündedir (Murnighan ve Saxon, 1998).

Takagishi vd. (2010), karmaşık bir yapısı olmasına rağmen UG'yi, yalnızca bir eşitsizlikten kaçınma testi olma yanıyla kullanmışlardır. Burada, teklifler eşit olmadığında alıcılar zorunlu bir seçim ile karşı karşıya kalır: eşitsizliği kabul edebilir veya reddedebilir ve her oyuncu için sıfırdan bir dağılım gerçekleştirebilirler. Bununla birlikte, UG'de reddetmeler, eşitsizliğin basit bir şekilde reddedilmesinden ziyade, eşitsiz tekliflerde bulunan teklifçileri cezalandırma arzusuyla motive edilebilir. Her ne kadar bazı UG'ler çocuklarla ilgili varsayımsal ödüller kullanmış olsalar da sonuçların gerçekçiliği açısından çocukların eşitlik elde etmek için şeker gibi gerçek bir ödülü reddetmeleri gerektiği oyunlar daha ikna edicidir. Bir yüz yüze UG'de, 
dezavantajlı bir teklif alan çocukların yaklaşık yarısı (yaş ortalaması: 5-6) teklifi reddetmiştir. Aynı çalışmada, sadece dört çocuğa avantajlı eşitsizlik sunulmuş ve hepsi bunu kabul etmiştir (Takagishi vd., 2010).

Blake ve Rand (2010) 3-9 yaş aralığındaki çocukların pazarlık gücünü elinde tuttuğunda ne kadar adil davranış biçimi göstereceklerine ilişkin bir çalışma yapmışlar, ancak oyunda pazarlık aracı olarak çocukların en sevdikleri çıkartmaları kullanmışlardır. Bu çalışmada amaç, kaynak değerinin çocukların adalet duygularını ne yönde etkileyeceğini araştırmak olarak belirtilmiştir. Çalışma sonucunda çocukların adalet duyguları adil olmaları gereken konunun onlar için önemi ile ilişkili bulunmuştur. 288 çocukla yapılan söz konusu çalışmada, çocukların sosyo-ekonomik düzeylerinin aldıkları kararlarda ne ölçüde etkili olduğu konusunun belirsiz olduğu bu konuda daha fazla çalışmanın gerekliliği ayrıca vurgulanmaktadır. Gelişim psikologları, çocuklarda adalet bilincini araştırmak için davranışsal iktisat yöntemlerini henüz yeni kullanmaya başlamışlardır. Bu deneylerden elde edilen sonuçlar, 3-4 yaş arası çocukların bazı kaynakları paylaşmaya istekli olduklarını, ancak 7 yaşına kadar eşit paylaşım tercihinin ortaya çıkmadığını göstermektedir. Mevcut deney, özellikle orta ve üst sosyo-ekonomik statü aileleri olan Amerikalı çocuklar arasında fedakâr davranışın nasıl ortaya çıktığı konusundaki anlayışımıza üç katkı sağlamaktadır. İlk olarak, eşitlikçi davranan çocukların oranının yaşla birlikte arttığı görülmektedir. İkincisi, çocukların eşitlik tercihlerinin söz konusu kaynağa nasıl değer verdiklerine bağlı olarak değişmektedir. $\mathrm{Bu}$ değer etkisi 3 yaşındakiler için belirgindir ve en azından ilkokul yıllarında sabit kalır. Üçüncüsü, sonuçlar fedakârlığın temelini oluşturan bilişsel süreçlerin ve bu süreçlerin gelişimde nasıl ortaya çıktıklarının bir açıklamasını sunmaktadır. Özellikle, paylaşma ya da paylaşmama kararı ve elindekinin ne kadarını paylaşacağı kararı, farklı gelişimsel seviyelerde ayrı süreçler olarak görünmektedir. Eşitlik konusunda çocukların sezgilerinin kökenleri net değildir. Çocuk gelişimindeki çalışmalardan 3 yaşından küçük çocukların bir norm olarak eşit bir bölünmenin farkında oldukları bilinmektedir. Bazı çalışmalar, çocukların kültürlerindeki yetişkin davranışları üzerindeki adalet davranışlarını modellediklerini iddia etmektedir. Çocuklar diğerlerinden eşitlik normlarını öğrenebilirken, mevcut araştırmalar bu normları katı bir şekilde uygulamadıklarını göstermektedir (Blake ve Rand, 2010).

Moore (2009) ve Fehr vd. (2008) benzer çalışmalar gerçekleştirerek deney grubunu oluşturan çocukların paylaşması için şeker kullanmışlardır. İkili gruplar halinde deneye alınan çocuklardan şekerleri paylaşmaları istemiştir. Çocuklar, avantajlı eşitsizlik (kendisi için iki şeker ve karşı tarafın hiç şekerinin olmaması) ile eşit bir paylaşım arasında seçim yapmalıdır. Böylece, eşit alternatifi seçerken çocuklar bir şekeri feda etmek zorunda kalacaklardır. Ancak her iki durumda da biraz şeker alacaklardır. Her iki çalışmada da alıcının kimliğinin sonuçları etkileyip etkilemeyeceği çıkarımı için de gözlem yapılmıştır. Sonuçta Moore (2009)'a göre paylaşımın alıcıya bağlı olarak değiştiği ortaya çıkmıştır. 3-6 yaş arasındaki çocuklarda, alıcının yetişkin bir araştırmacı veya çocuğun bir arkadaşı olması durumunda eşit seçeneği seçme olasılığı daha yüksek olmuştur. Ancak, alıcı yabancı biriyken, çocuklar avantajlı seçeneği seçmektedirler (Moore, 2009). Fehr vd. (2008)'e göre ise 8 yaşından küçük çocuklar, alıcıdan bağımsız olarak avantajlı seçeneği seçmişlerdir (Fehr vd., 2008). Özetle paylaşım bir arkadaşıyla veya bir yetişkinle olacağı zaman, çocukların eşit olarak paylaşmaları yani adil davranış sergilemeleri daha muhtemeldir.

LoBue vd. (2010)'a göre genel olarak literatürde yer alan sonuçlar, her yaşta dezavantajlı eşitsizliğe karşı önemli bir sapma ve avantajlı eşitsizliğe karşı anlamlı bir olumlu tepki olduğunu ortaya koymuştur. Bir akranın daha büyük bir ödül almasını izlemek, dezavantajlı 
bir teklifi kabul etmeyi zorlaştırabilir. Buna karşılık, okul öncesi çocuklar bir akran önünde daha büyük bir ödül aldıklarında, bu avantajlı eşitsizlikten memnun olmuşlardır (LoBue vd., 2010).

Riedl vd. (2015), 3-5 yaş aralığındaki çocukların davranışlarına odaklanmışlardır. Deneysel çalışmaya çocukların akranları ile bir de kukla dahil edilmiştir. Burada hedef, döner bir masa etrafında oturan çocuklara rastgele dağıtılan eşyaların çocuklar tarafından nasıl paylaşılacağını izlemek ve kuklanın adaleti bozucu müdahalede bulunmasına verecekleri tepkileri gözlemlemektir. Deneyde çocuklara kuklayı bu davranışına karşın cezalandırma hakkı da verilmiştir. Elde edilen sonuçlara göre; bu yaş grubundaki çocuklar, ceza motivasyonu olduğunda hem kendileri hem de diğerleri için adaletsizlik durumunda üçüncü şahsa (kuklaya) ceza vermekten çekinmemişlerdir. Deneyin bu noktasına kadar eşyaların sahiplerine adil bir şekilde teslim edilmesinin sağlanması karşılığında çocuklara ödül olarak kurabiye verilmiştir. Ancak Riedl vd. (2015), oyunda küçük bir değişiklik yaparak, çocukların davranışlarını ödülün (kurabiyenin) kaldırılması durumunda gözlemlendiklerinde, eşyaların adil dağılımından ziyade ilk dağıtıldığı halindeki gibi, orijinal sahiplerine teslim edildiğini dolayısıyla bu noktada kuklaya da eşit davrandıklarını ortaya koymuşlardır. Dolayısıyla çocukların adalet duygusunun belli bir işleyişi olduğunu ancak içinde bulunulan koşullar değiştirildiğinde ceza ve/veya intikam duygusunun çocuklarda kalıcı olmadığı da çalışmanın vurgulanan sonuçları arasındadır (Riedl vd., 2015).

Shaw ve Olson (2014), 5 ve 8 yaş aralığındaki çocuklara üç farklı deney uygulamışlardır. Birinci deneyde, çocuklara iki seçenek sunulmuştur. İlk seçenekte çocuklardan birinin diğerine göre daha fazla ödül elde edebileceği bir çark, ikinci seçenekte eşit ödül elde etme şansına sahip oldukları bir çark sunulmuştur. Bu deneyde çocukların fazla ödülü kimin alacağının belli olmadığı durumu reddederek eşit ödül çarkını seçtikleri gözlemlenmiştir. İkinci ve üçüncü deneylerde eşit ve eşitsiz çarklara ek olarak ödülleri çöpe atma seçeneği de eklenmiştir. Bu durumda da herhangi bir eşitsizlik ortaya çıktığında, yaşla doğru orantılı olarak artan bir eğilimde, çocuklar eşitliğ i sağlamak için elindekileri çöpe atmayı seçmişlerdir (Shaw ve Olson, 2014).

Enesco ve Warneken (2015), yarısı 3, yarısı 5 yaşında olan 72 çocukla gerçekleştirdikleri uygulamada, bir alıcının daha sonra iyiliğe karşılık verip veremeyeceğine bağlı olarak çocukların paylaşımlarını hangi yaşta bilinçli olarak yönlendirebildiklerini araştırmışlardır. Sonuçlar, 5 yaşındaki çocukların, karşılık veremeyen bir ortağa göre daha sonra karşılık veren bir ortakla daha fazla kaynak paylaşarak karşılık verme olasılığına duyarlı olduğunu göstermiştir. Buna karşılık, 3 yaşındakilerin her iki durumda da aynı miktarı paylaştıkları ve bunun ortaklarının sonradan verecekleri tepkiyi hesaba katmadıklarını gösterdiğini belirtmişlerdir. İkinci olarak, karşılıklı paylaşım için potansiyel olarak önemli bir ön koşul olarak hazzı erteleme yeteneğini araştırmışlardır. Burada, çocukların daha iyi ödüller için beklemek zorunda kalma eğilimlerinin, başkalarıyla daha adil paylaşımda bulunma istekleri ile olumlu yönde ilişkili olduğunu ortaya koymuşlardır. İlginç bir şekilde, daha iyi ödül için beklemek ve paylaşmak arasındaki ilişki, karşılıklılı̆̆ın ortaya çıkabileceği durumla sınırlı değil, daha çok çocukların her iki koşulda başkalarıyla paylaşma konusundaki genel kararlarıyla sınırlı olması da çalışmanın bulguları arasındadır (Ernesco ve Warneken, 2015). Gummerum ve Chu (2014), 132'si yetişkin olmak üzere 443 denek ile gerçekleştirdikleri deneylerinde, adalet duygusunun yetişkinlerde ve çocuklarda davranışlara yansıması yine temel ekonomi oyunlarından esinlenerek uyarlanmış oyunlar ile gözlemlenmiştir. Burada benzer çalışmalarda da olduğu gibi yine bir ceza faktörü oyunlara eklenmiştir. Karşılaşılan en 
temel sonuç, daha önce bahsettiğimiz çalışmalardakine benzer şekilde oyuncuların verdiği kararlarda yaş faktörünün oldukça önemli bir etkendir $\mathrm{Bu}$ çalışmada da davranış değişikliğinin görüldüğü yaş sınırı 8 yaş olmuştur. Denekler eşit olmayan dezavantajlı teklifleri, eşit olan avantajlı eşitsizlik durumuna göre daha fazla cezalandırmışlardır. Öte yandan 12 yaş üzeri denekler cezalandırmaya karar verirken eşitsizliğe neden olan tarafın iyi niyetli olup olmadığını da göz önünde bulundurmuşlardır. 15 yaş üzeri bu unsuru kesinlikle kararlarına dâhil ederken, 12-15 yaş aralığının karar verme süresinin uzadığı izlenmiştir. Ancak özellikle 8 yaş ve altında niyet unsurunun etkisi gözlemlenmemiştir. Dolayısıyla çalışmanın ulaştı̆̆ 1 yargı, ergenlerin ve yetişkinlerin kasıt temelli ceza verme olasılıklarının çocuklardan daha yüksek olduğu yönündedir (Gummerum ve Chu, 2014).

Elenbaas vd. (2016) çalışmalarında, çocukların bir kaynak tahsisi görevinde sosyal eşitsizlikleri düzeltip düzeltmediğini araştırmak amacıyla, farklı ırksal geçmişlere sahip toplam 185 akran çocuk arasındaki okul malzemelerinin eşitsizliği ortamını yaratarak analiz yapmışlardır. Çocuklar hem Afro-Amerikan/Avrupa-Amerikan kökenlerine göre hem de yaş gruplarına göre (5-6 ve 10-11) ayrılarak gözlemlenmiştir. Çocukların eşitsizliğin sebep olduğu haksızlığ nasıl yargıladıkları, yeni kaynakları ırksal iç-grup ve dış-grup alıcılara nasıl tahsis ettikleri, alternatif tahsis stratejilerini nasıl değerlendirdikleri ve kararlarını nasıl gerekçelendirdiklerine dair değerlendirmeler çalışmaya dâhil edilmiştir. Daha küçük yaştaki çocuklar, grup içini tercih ederlerken, tercihlerinde grup içinde veya grup dışında dezavantajlı bir şeye tanık olup olmadıklarına bağlı olarak farklı kararlar vermişlerdir. Yaşların artması ile çocukların, okul malzemelerine eşit erişimin önemi ve geçmiş eşitsizliklerin düzeltilmesi konusunda giderek daha fazla akıl yürüttüğü çalışmanın bulguları arasındadır. Yaşı daha büyük olan çocuklar, herhangi bir ayrım yapmaksızın eşitsizlikleri giderme yönünde davranış sergilemişlerdir (Eleenbaas vd., 2016).

Rackozy vd. (2016), yine bir kuklayı dâhil ettikleri deneysel çalışmalarında 3 ve 5 yaşındaki çocuklarla çalışmışlardır. Çalışmaya her iki yaş grubundan da 24 çocuk olmak üzere toplam 48 çocuğu dâhil etmişlerdir. Deneyde kukla tarafından kaynak dağılımının gerçekleştirilmesi sırasında çocukların neredeyse tamamının adaletsizliğe tepki gösterdiği ancak 5 yaşındakilerin artık daha net ifadelerle doğrudan eşitsizliğe itiraz ettikleri gözlemlenmiştir. Çalışma, literatürde yer alan pek çok çalışma gibi çocuklarda adalet duygusunun gelişiminin davranışlara yansımasında yaş faktörünü sınamakla sınırlı kalmıştır. Ancak her koşulda bulgular çocukların tahmin edilenden çok daha önce, kişisel olarak doğrudan etkilenip etkilenmedikleri fark etmeksizin, adil dağıtım ilkelerini normatif olarak anladıklarını göstermektedir (Rackozy vd., 2016).

Literatürde çocukların adalet duygularının davranışlarına nasıl yansıdığına ilişkin mevcut pek çok çalışma olmasına karşın bunlardan çoğunluğu yukarıda belirtilen kaynaklardaki gibi pazarlığa dayalı oyunlar ve/veya taraflardan birinin karar vermesine dayalı oyun kurgularıyla gözlemlenmiştir. Çocukların kendilerinin karar vermediği, buna karşın adalet duygusunun belirgin olarak tepkilerine yansıdığı durumlar için çocukların sergiledikleri davranışları gözlemlemeye yönelik çalışmalar oldukça kısıtlıdır. Çalışma, bu deneysel gözlemi yapmak, konuya ailelerin sosyo-ekonomik durumlarını dahil etmek ve sonuçları ampirik bir çalışmaya dönüştürmek açısından literatüre katkı sağlayacaktır. Buna ek olarak çocukların adalet duygularının adalet bilincine dönüşmesi için gerekli olan pekiştireç onların hukuk sistemine dair bilgi ile donatılmaları, bu sistemde kendi yerlerini ve haklarını bilmeleri ile olacaktır. Milli Eğitim Bakanlığı'nda kurulmuş olan "Hukuk Bilincini Geliştirme Komisyonu" ile konunun önemi de vurgulanmış olmaktadır. Bu konuda ise Halıcı ve Van (2016) çalışmalarında 
ortaokullara yönelik bir anket gerçekleştirerek okullarda seçmeli olarak verilen "hukuk ve adalet" derslerinin adalet bilinci üzerindeki etkisini araştırmışlardır. Anket sonuçları analiz edildiğinde bu derslerin, çocukların hukuki sorumluluk algısını ve hukuka ilgi algısını farklı etkilediği ortaya konmuştur. Özellikle kız çocuklarında hukuki sorumluluk algısı daha fazla artarken, erkek çocuklarında hukuka ilgi algısının daha düşük düzeyde arttığını ortaya konmuştur. Analiz sonuçları genel olarak değerlendirildiğinde ise söz konusu dersin, hukuka ilişkin birtakım algıları yükselttiği ancak derslerin içerik olarak yetersiz ve çocukların düzeyi için son derece soyut kavramlar olarak kaldığı, bu nedenle hukuk bilincinin bu dersle beklenen ölçüde gelişmediği tespit edilmiştir (Halıcı ve Van, 2016). Konuyla ilgili yerli literatürde çok fazla çalışma bulunmadığından, çalışma konumuzun, çocuklara uygulamada adalet duygusunu vurgulama yönü ile akılda kalıcı ve somut, adalet sisteminde çocukların kendi yerlerini fark etmeleri açısından bilinç kazandırıcı nitelikte olacaktır. Ailelerin ekonomik durum ve sosyal statülerinin analize dahil edilmesi ise çalışmanın bir diğer yenilikçi yönü olacaktır.

\section{Yöntem ve Bulgular}

Önceki bölümde ele alınan adalet duygusunun çocuklarda dolayısıyla bireyde gelişimi konusu literatürde hâlâ tartışmalı olduğu için çocuklarla yapılan çalışmalar henüz sınırlı boyutlardadır. Bununla birlikte söz konusu çalışmalar genellikle adalet duygusunun bireyde yaşa göre ilkel döneminden itibaren adım adım geliştiğini ve içinde yetişilen koşullara göre şekillenip yerleştiği fikrini doğurmaktadır.

Çalışma konuyla ilişkili ampirik analizin yapılabilmesi amacıyla ilk öğretim çağındaki çocuklarla gerçekleştirilen oyun uygulaması ile bu yaş gurubundaki çocuklarda adalet duygusunun hangi faktörlerden etkilenerek şekillendiğini araştırma amacı taşımaktadır.

\section{Yöntem}

Çalışmaya ilişkin ampirik analiz için iki farklı yöntemle derlenen veriler kullanılmıştır. Bunlardan birincisi uygulaması çocuklarla yapılan deneysel gözlem çalışmasıdır. İkincisi ise çocukların ailelerinin sosyo-ekonomik koşullarına (yaşları, kardeş sayısı, ailenin -gelir düzeyi, medeni durumu, eğitim durumu, mülkiyet durumu-) ilişkin okul kayıtlarından elde edilen bilgilerin okul yönetimi ve ailelerin rızası ile derlenmesi yoluyla veri elde edilmesi olmuştur. Deneysel gözlem çalışmasının sonuçları ile derleme yoluyla elde edilen veriler, daha sonra birleştirilerek birlikte analize tabi tutulmuşlardır.

$\mathrm{Bu}$ çalışmada, ilköğretim çağındaki 106 çocuk için öncelikle basit bir oyun düzeneği kurulmuştur. Uygulama, örneklem için seçilen ilköğretim okulunun uygun bir sınıfında ve eğitim-öğretim faaliyetlerinin aksamayacağı saatler dikkate alınarak gerçekleştirilmiştir. Oyun, gruplar halinde ortama alınan çocuklar için eşit sayıda dağıtılmış pinpon toplarının bir kaptan diğerine aktarılması ile gerçekleştirilmiştir. Böylelikle çocuklarda eşit iş yaptıkları algısının oluşması sağlanmıştır. Top taşıma işlemi sona erdiğinde ödül, aynı işi yapan çocuklar arasında adaletsiz olarak dağıtılmıştır. Çocukların, ödüllerin adaletsiz dağılımına verdikleri tepkiler görüntü kaydı ile kayıt altına alınmıştır. Daha sonra görüntü kayıtları detaylı bir şekilde izlenerek çocukların avantajlı (çocuğun kendisinin daha fazla ödül aldığı) ve dezavantajlı (çocuğun kendisinin daha az ödül aldığı) eşitsizliklere verdikleri tepkiler analize uygun bir döküm haline getirilmiştir. Sözü edilen uygulama sırasında çocuklar uygun yaş gruplarına göre (1. sinıflar, 2. sinıflar, 3. sinıflar ve 4 . siniflar olmak üzere) gruplandırılmışlardır. 
Her iki veri grubu daha sonra uygun analiz programında birleştirilerek, bağımlı değişken olarak çocukların, adaletsiz ödül dağıtımına verdileri tepkinin ailelerin sosyo-ekonomik durumu hakkında fikir veren diğer bağımsız değişkenlerle ilişkili olup olmadığı ikili korelasyon testleri ile araştırılmıştır.

Söz konusu deneysel gözlem için 100 öğrencinin yeterli olduğu verisine; Yazıcıŏ̆lu ve Erdoğan (2004) tarafından, istatistiksel analizler için belirli evren büyüklüklerinden alınması gerekli örneklem miktarları hesaplamalarından ulaşılmıştır. Kaynakta yer alan hesaplamalar Tablo 1'de verilmektedir.

Tablo 1. $\alpha=0.05$ İçin Örneklem Büyüklükleri

\begin{tabular}{|c|c|c|c|c|c|c|c|c|c|}
\hline \multirow[t]{3}{*}{$\begin{array}{l}\text { Evren } \\
\text { Büyüklüğgü }\end{array}$} & \multicolumn{3}{|c|}{$\begin{array}{l}\text { +- } 0.03 \text { Örnekleme Hatas } 1 \\
\text { (D) }\end{array}$} & \multicolumn{3}{|c|}{$\begin{array}{l}+0.05 \text { Örnekleme Hatas } 1 \\
\text { (D) }\end{array}$} & \multicolumn{3}{|c|}{$\begin{array}{l}+0.10 \text { Örnekleme Hatası } \\
\text { (D) }\end{array}$} \\
\hline & $\mathrm{p}=0.5$ & $\mathrm{p}=0.8$ & $\mathrm{p}=0.3$ & $\mathrm{p}=0.5$ & $\mathrm{p}=0.8$ & $\mathrm{p}=0.3$ & $\mathrm{p}=0.5$ & $\mathrm{p}=0.8$ & $\mathrm{p}=0.3$ \\
\hline & $q=0.5$ & $q=0.2$ & $\mathrm{q}=0.7$ & $q=0.5$ & $\mathrm{q}=0.2$ & $\mathrm{q}=0.7$ & $q=0.5$ & $q=0.2$ & $q=0.7$ \\
\hline 100 & 92 & 87 & 90 & 80 & 71 & 77 & 49 & 38 & 45 \\
\hline 500 & 341 & 289 & 321 & 217 & 165 & 196 & 81 & 55 & 70 \\
\hline 750 & 441 & 358 & 409 & 254 & 185 & 226 & 85 & 57 & 73 \\
\hline 1000 & 516 & 406 & 473 & 278 & 198 & 244 & 88 & 58 & 75 \\
\hline 2500 & 748 & 537 & 660 & 333 & 224 & 286 & 93 & 60 & 78 \\
\hline 5000 & 880 & 601 & 760 & 357 & 234 & 303 & 94 & 61 & 79 \\
\hline 10000 & 964 & 639 & 823 & 370 & 240 & 313 & 95 & 61 & 80 \\
\hline 25000 & 1023 & 665 & 865 & 378 & 244 & 319 & 96 & 61 & 80 \\
\hline 50000 & 1045 & 674 & 881 & 381 & 245 & 321 & 96 & 61 & 81 \\
\hline 100000 & 1056 & 678 & 888 & 383 & 245 & 322 & 96 & 61 & 81 \\
\hline 1000000 & 1066 & 682 & 896 & 384 & 246 & 323 & 96 & 61 & 81 \\
\hline 100 milyon & 1067 & 683 & 896 & 384 & 245 & 323 & 96 & 61 & 81 \\
\hline
\end{tabular}

Kaynak: Yazıcıŏ̆lu ve Erdoğan, 2004, s. 50.

Literatürde gerçekleştirilen araştırmalar için sıkça kullanılan bu örneklem sayısı belirleme yöntemine göre $\% 10$ örneklem hatası ve $\alpha=0,05$ anlamlılık düzeyinde 25000 (yirmibeş bin) ve üzeri evren büyüklüğü için örneklem sayısı 96 olarak hesaplanmıştır (Tablo 1). Milli Eğitim Bakanlığı'nın yayınlamış olduğu 2017-2018 eğitim-öğretim yılı istatistiklerine göre Manisa İli'nde ilköğretim (ilkokullar) öğrenci sayısı 35.316 erkek ve 35.969 kız öğrenci olmak üzere toplamda 71.285 olarak açıklanmıştır. Ancak; tabloda da görüleceği gibi evren büyüklügüüün 25.000 üzeri olması halinde örneklem sayısındaki artış, sonuçları anlamlı düzeyde değiştirmemektedir. Bu nedenle çalışmamızda örneklem sayısı 100 ile sınırlandırılmıştır. Bununla birlikte ilköğretim çağındaki çocukların gönüllü katılım sağlaması dolayısıyla çalışmamızın örneklem sayısı 106 olmuştur.

\section{Veri Seti}

İki farklı yöntemle elde edilen veriler tanımlama açısından değerlendirildiğinde, veri setini oluşturan her bir değişkenin kendi içerisinde gösterdiği dağılım ayrı ayrı değerlendirilebilir. Buna göre Tablo 2' de kardeş sayısı bilgileri yer almaktadır. 
Tablo 2. Kardeş Sayısı

\begin{tabular}{l|cc}
\multicolumn{1}{l|}{ SAYI } & FREKANS & YÜZDE \\
\hline 0 & 6 & 5,7 \\
1 & 19 & 17,9 \\
2 & 56 & 52,8 \\
3 & 22 & 20,8 \\
4 & 1 & 0,9 \\
5 & 2 & 1,9 \\
Toplam & 106 & 100
\end{tabular}

Tablo 2' de görüldüğü gibi araştırmaya dahil olan 106 çocuğun 56'sı kendisi dışında iki kardeşe daha sahiptir. Diğer bir deyişle araştırmaya \%52,8 oranı ile üç çocuklu aileler dahil olmuştur. Hiç kardeşi olmayan çocuk sayısı yani tek çocuklu aile sayısı ise örneklemimiz içerisinde 6 tane olup oransal olarak örneklemin $\% 5,7$ 'sine denk gelmektedir. Bu sonuca göre çocukların \%94,3'ünün paylaşımın nispeten yüksek olduğu ortamda büyüdügü söylenebilir.

Çocuklardaki adalet anlayışının gelişmesinde rol oynayabileceğini düşündüğümüz diğer unsur ailenin eğitim düzeyidir. Her ne kadar adalet insan vicdanı ile ilişkili bir olgu olsa da anne ve babanın eğitim düzeyinin çocuğa bilinçli olarak verilen değerler eğitimi üzerinde etkisi olacaktır. Bu bağlamda ikinci bağımsız değişkenimiz anne ve babanın eğitim düzeyi olarak alınmıştır. Bu verinin dağılımı Tablo 3'de görülmektedir.

Tablo 3. Anne- Baba Eğitim Düzeyi

\begin{tabular}{l|cccc}
\multicolumn{2}{c}{ ANNE } & \multicolumn{2}{c}{ BABA } \\
\hline EĞİTIM DÜZEYİ & Frekans & Yüzde & Frekans & Yüzde \\
Yok & 1 & 0,9 & 40 & 37,7 \\
İlköğretim & 49 & 46,2 & 38 & 35,8 \\
Lise & 34 & 32,1 & 26 & 24,5 \\
Lisans & 22 & 20,8 & 2 & 1,9 \\
Toplam & 106 & 100 & 106 & 100
\end{tabular}

Tablo 3, ele alınan örneklemde, annelerin \%52,9'unun en az lise mezunu olduğunu ifade etmektedir. Buna karşın ilköğretim mezunu annelerin sayısı da \%46,2'lik bir orana denk gelmektedir ki bu da oldukça yüksek bir orandır. Baba eğitim düzeylerine bakıldığında örneklem grubunda en fazla lise mezunu olan babaların oranı $\% 73,5$ olarak görülmektedir. Bu oldukça yüksek bir oran olup anne eğitim düzeyi verileriyle birlikte yorumlandığında, örneklem grubunda ailelerin eğitim düzeyinin düşük olduğunu söylemek mümkündür.

Çalışmamızda adaletsiz ödül dağılımına verilerin tepkileri etkileyip etkilemediği araştırılan diğer bir değişken gelir durumudur. Tablo 4 'te gelir düzeyi verileri açılanmaktadır. 


\section{Tablo 4. Gelir Düzeyi}

\begin{tabular}{l|cc} 
Gelir Düzeyi & Frekans & Yüzde \\
\hline Düşük & 9 & 8,5 \\
Orta & 88 & 83 \\
Yüksek & 9 & 8,5 \\
Toplam & 106 & 100
\end{tabular}

Tabloda da görülmektedir ki; araştırma grubunun $\% 83$ gibi yüksek bir oranı orta gelir düzeyine sahiptir. Örneklemde düşük ve yüksek gelir grubuna dahil ailelerin sayılarının eşit olması rastlantısal olarak gerçekleşmiştir.

Ebeveynlerin medeni durumu çocuklar üzerinde farklı etkiler bırakmaktadır. Bu nedenle, bu değişkenin etkinliğini araştırmanın anlamlı olacağ düşünülmüşstür. Tablo 5, örneklemimizde yer alan ebeveynlerin medeni durumlarını özetlemektedir.

\begin{tabular}{l|cc} 
Tablo 5. Ebeveyn & \multicolumn{3}{c}{ Medeni Durumu } \\
Medeni Durum & Frekans & Yüzde \\
\hline Evli & 100 & 94,3 \\
Ayr1 & 6 & 5,7 \\
Toplam & 106 & 100
\end{tabular}

Tablo 5'e göre denek grubunu oluşturan çocukların \%94,3'ünün öz anne babaları birbirleri ile evlidir. Yalnızca 6 çocuğun anne ve babası ayrı olup, örneklemde anne ve/veya babası vefat etmiş çocuk yoktur.

Tablo 6, günümüzde gelir üzerinde önemli bir gider kaleminin olmasına ya da önemli bir giderin ortadan kalkmasına neden olduğu için aynı zamanda yaşam koşullarının belirleyicileri arasında yer alan kira gideri değişkenine ilişkindir. "Konut mülkiyeti" başlı̆̆ında araştırmaya dahil ettiğimiz verinin dağılımı Tablo 6'de görüldüğü gibidir.

\section{Tablo 6. Konut Mülkiyeti}

\begin{tabular}{l|cc} 
Konut Mülkiyeti & Frekans & Yüzde \\
\hline Kira & 21 & 19,8 \\
Kendilerine Ait & 85 & 80,2 \\
Toplam & 106 & 100
\end{tabular}

Tablo 6, örnekleme dahil olan ailelerin \%80,2 gibi yüksek bir oranla kendilerine ait bir evde oturduklarını göstermektedir.

Araştırmamızda bağımlı değişken olarak yer alan ve ölçmeye çalıştığımız "verilen tepki" ye ilişkin dağılım ise Tablo 7'de görülmektedir.

Tablo 7. Verilen Tepki

\begin{tabular}{l|cc} 
Verilen Tepki & Frekans & Yüzde \\
\hline Tepki Yok & 77 & 72,6 \\
KHU* $^{*}$ & 18 & 17,0 \\
BHU** & 11 & 10,4 \\
Toplam & 106 & 100
\end{tabular}


KHU: Kendisi haksızlığa uğradığında tepki vermek

BHU: Başkası haksızlığa uğradığında tepki vermek

Literatürdeki çalışmalara bakıldığında pek çok durumda çocukların pozitif ya da negatif adaletsizliğe bir şekilde tepkilerinin olduğu görülmektedir. Ancak çalışmamızla kıyaslanabilir olan ve bizim de örnek aldığımız bu çalışmaların tamamı yabancı literatüre aittir. Tablo 7'de de görüldüğü gibi analizimizdeki oyuna dahil olan çocukların \%72,6'sı gibi yüksek bir oranı adaletsiz dağıtıma tepki vermemişlerdir. Bu durum, konunun disiplinler arası bir çalışma ile ayrıca irdelenmesi gerektiğini düşündürmektedir. Çocukların \%17'si kendisi haksızlığa uğradığında (negatif eşitsizlik durumunda) tepki verirken, yalnızca \%10,4'ü başkası haksızlığa uğradığında tepkisini dile getirmiştir.

Araştırmada yer alan yedi değişken tablolar halinde özetlendiği gibi olup dağılım özellikleri açıkça görülmektedir. Genel olarak bakılacak olursa veri setimiz birden fazla kardeşe sahip, öz anne-babasıyla yaşayan, gelir ve ebeveynlerinin eğitimleri açısından orta düzeyde yer alan, yaş aralığ 1 7-10 olan çocuklardan elde edilen verilerden oluşmaktadır.

\section{Bulgular}

Gerçekleştirilen analiz ikili korelasyonları veren temel bir analiz yöntemidir. Buna göre her bir korelasyon araştırmasında verilen tepki bağımlı değişken olarak sabit tutulmuştur. Bağımsız değişkenler ise sırasıyla kardeş sayısı, gelir düzeyi, annenin eğitim düzeyi, babanın eğitim düzeyi, ebeveynlerin medeni durumu, oturulan evin sahiplik durumu olarak belirlenmiştir. Değişkenlerin normal dağılım gösterdiği kabul edilmiştir.

Söz konusu değişkenlerden gelir düzeyi ve ev sahipliği, doğrudan ekonomik durumun verilen tepki dolayısıyla çocuklarda adalet duygusunun gelişimine olan etkisi konusunda fikir vermektedir. Ele alınan değişkenlerin çocukların adaletsizlik karşısında verdikleri tepkiyi etkileyip etkilemediği, etkiliyorsa ne oranda etkilediğini gösteren analiz sonuçları sırasıyla tablolaştırılmıştır. Buna göre Tablo 8'de görülen korelasyon katsayıları \%1 anlamlılık düzeyinde geçerlidir.

\section{Tablo 8. Verilen Tepki Bağımlı Değişkeninin Bağımsız Değişkenlerle} Korelasyonu

\begin{tabular}{l|ccc} 
& Pearson Korelasyonu & $\begin{array}{c}\text { Sig. } \\
\text { (2-Tailed) }\end{array}$ & N \\
\hline Kardeş Sayısi-Verilen Tepki & $-0,72$ & 0,461 & 106 \\
Anne Eğitim Düzeyi-Verilen Tepki & $-0,001$ & 0,92 & 106 \\
Baba Eğitim Düzeyi-Verilen Tepki & $-0,089$ & 0,363 & 106 \\
Gelir Düzeyi-Verilen Tepki & 0,069 & 0,483 & 106 \\
Ebeveyn Medeni Durumu-Verilen Tepki & 0,168 & 0,085 & 106 \\
Ev Sahipliği-Verilen Tepki & $-0,033$ & 0,738 & 106
\end{tabular}

Pearson Korelasyon Katsayısı -1 ile +1 arasında değer almaktadır. Burada katsayı değeri-/+ 1'e yaklaştıkça iki değişken arasındaki ilişki güçlenmektedir. Negatif işaret değişkenler arasında 
ters yönlü bir ilişkinin varlığını, pozitif işaret ise değişkenler arasında aynı yönlü bir ilişkinin varlığını ifade etmektedir. Bu bağlamda Tablo 8'de görülen katsayılara göre sonuçları yorumladığımızda gelir durumu ve ebeveynlerin medeni durumu dişında tüm bağımsız değişkenlerin bağımlı değişken ile ters yönlü bir ilişki içerisinde olduğu anlaşılmaktadır. Tek tek katsayılar yorumlandığında en güçlü negatif ilişkinin -0,72 ile kardeş sayısı ile verilen tepki arasında olduğunu söylemek mümkündür. İşaretin negatif olması dolayısıyla bu güçlü ilişki, kardeş sayısının artmasıyla birlikte eşitsizliğe verilen tepkinin azalması gibi bir zıtlık barındırmaktadır. Anne ve baba eğitim düzeyleri ile gelir düzeyi ve ev sahipliği değişkenleri ise çocukların adaletsiz ödül dağılımına verdikleri tepkiler üzerinde yine negatif yönlü ancak oldukça zayıf etkiye sahip değişkenlerdir. Pozitif yönlü ilişkiye sahip olmakla birlikte kardeş sayısından sonra en güçlü ilişkinin görüldüğü değişken ise ebeveynlerin medeni durumudur.

\section{Teşekkür ve Bilgilendirme}

Bu çalışma, Manisa Celal Bayar Üniversitesi Bilimsel Araştırma Projeleri Koordinasyon Birimi tarafından desteklenen 2019-010 nolu "İlköğretim Çağındaki Çocuklarda Adalet Bilinci ve Ekonomik Koşulların Adalet Bilinci Üzerindeki Etkisi: Manisa İli Örneği” adlı proje çalışmasından türetilmiştir. Desteklerinden dolayı Bilimsel Araştırma Projeleri Koordinasyon Birimi'ne teşekkür ederiz.

\section{Sonuç}

Geçmişten günümüze adalet duygusunun tek başına temel değerlerden biri olarak var olduğu konusunda geniş bir düşünsel zemin mevcuttur. Felsefi zeminde konu genellikle devletin adalet sağlaması üzerine şekillense de bu yöndeki fikirler, birey için adaletin vicdani bir duygu olarak, kendisini fark etmesiyle birlikte ortaya çıktığı temeli üzerine oturmaktadır.

Konuya ilişkin tartışmalar, adalet duygusunun içselleştirilmesi noktasında sosyal öğrenme teorileri, ekonomik teoriler, biyolojik teoriler ve psikolojik teoriler çerçevesinde sürmektedir. Bununla birlikte son yıllarda özellikle davranışsal iktisadın etkileri ile öne çıkan araştırmalar bireylerin aldıkları kararları ölçme konusunda ekonomi oyunlarını kullanmaya başlamış bu da adalet duygusunun davranışlara yansımasının hangi koşullarda nasıl gerçekleştiği noktasında farklı çalışmalara zemin hazırlamıştır. Özellikle adalet duygusunun insandaki gelişimi konusunda kökene doğru inmek isteyen araştırmacılar, ekonomi oyunlarını çocuklar için uyarlayarak konuyu zenginleştirmiş ve çocukluğun hangi döneminde bu duygunun fark edilmeye başlandığ 1 ve davranışlarda gözlemlenebilir olduğunu irdelemişlerdir. Genellikle elde edilen sonuçlar, tahmin edilenden çok daha erken yaşlarda (3-5 aralığında), ilkel düzeyde de olsa adaletsizliğe tepkilerin görüldüğü 5-8 yaş aralığında bunun daha net ifadesinin ortaya çıktığı ancak 8 yaş ve üzerinde net olarak bu duygunun davranışlara yansıdığı yönündedir. Bununla birlikte çok az sayıda çalışma sosyo-ekonomik koşulların ya da başka unsurların adaletsizliğe verilen tepki üzerine etkisini araştırmıştır.

Çalışma mevcut literatür temelinde, "eşit işe eşit ödül” mantığı çerçevesinde hazırlanmış basit bir oyunla çocukların adaletsizliğe gösterdikleri tepkileri araştırılmıştır. Genel olarak değerlendirildiğinde; ulaştığımız sonuçlar ister kendisi pozitif ya da negatif eşitsizliğe maruz kalsın, ister başkasının eşitsizliğe maruz kaldığını görsün ilköğretim çağındaki çocukların adaletsizliğe verdikleri tepkinin, kardeş sayısı ve anne-babanın medeni durumundan yani; içinde bulundukları aile ortamından etkilendiğini göstermektedir. Yine de çalışmanın verilerine bakıldığında genel olarak adaletsizliğe tepki verme oranının oldukça düşük kaldığ 
görülmektedir. Deneye dâhil olan çocukların \%17'si kendisi haksızlığa uğradığında (negatif eşitsizlik durumunda) tepki verirken, yalnızca \%10,4'ünün başkası haksızlığa uğradığında tepki gösterdikleri görülmüştür. Diğer bir deyişle bir şekilde eşitsizliğe tepkisiz kalan çocukların oranı \%72,6 gibi oldukça yüksek bir oranken yalnızca \%27,4 oranında çocuk tepkisini ifade edebilmiştir. Ancak deney sırasında gözlemlenmekle birlikte sayısal olarak aktarılamayan bir nokta da konuya ilişkin çıkarımlarda bulunulması ve daha detaylı analizlere zemin hazırlaması açısından önemlidir. İzlemlerde dikkat çeken nokta çocukların eşitsizliğe tepki vermeseler de tamamen kayıtsız kalmamaları olmuştur. Yani tepkisizlik, bir umursamazlık ya da farkında olmama durumuna da tam olarak uymamaktadır. Çocuklar, fark ettikleri anda, eşitsizlikten hoşnut olmadıklarını belli eden tavırlar sergilemiş ancak eşitsizliği giderici yönde de müdahalede bulunmamışlardır. Bununla birlikte; eşitsizliğin dağıtıc tarafından giderilip giderilmeyeceğini gözlemleyerek bu beklentilerinin karşılanmaması durumunda memnuniyetsiz de olsa kabullenme davranışı sergilemişlerdir. Literatürdeki çalışmalara bakıldığında pek çok durumda çocukların pozitif ya da negatif adaletsizliğe bir şekilde tepkilerinin olduğu görülmektedir. Ancak bu çalışmayla kıyaslanabilir olan ve örnek alınan bu çalışmaların tamamı yabancı literatüre aittir. Bu durum konunun disiplinler arası bir çalışma ile ayrıca irdelenmesi gerektiğini düşündürmektedir. Çünkü yapılan deneyde çocukların adaletsizliği gidermesini bekledikleri dağıtıcı, sosyal anlamda da otoriteyi temsil etmektedir. Çocukların büyük çoğunluğunun orta gelir ve eğitim düzeyine sahip ailelerde yetiştiği göz önünde bulundurulduğunda bu noktanın kültürel yapı ile ilişkili olduğu da düşünülebilir.

Çalışmanın temel hedefi olarak vurgulanan noktada ise ekonomik koşulların çocukların adaletsizliğge verdikleri tepki ile ilişkisi 0,069 korelasyon katsayısı ile oldukça düşük kalmıştır. Bu durumda ekonomik koşullarla adaletsizliğe gösterilen tepkinin ilişkili olduğunu söylemek çalışmanın sonuçları açısından çok uygun olmayacaktır. Fakat tepkisizlik oranı oldukça yüksek olduğundan ilişkiyi tamamen yok saymak da tartışmalı olacaktır. 


\section{Kaynakça}

Benenson, J.F., Pascoe, J. \& Radmore. N. (2007). Children's alturistic behaviour in the dictator game. Evulation and Human Behavior, 28(3), 168-175.

Blake, P.R. \& Rand, D.G. (2010). Currency value moderates equity preference among young children. Evolution and Human Behavior, 31(3), 210-218.

Blake, P.R. \& McAuliffe, K.(2011). I had so much it didn't seem fair: Eight-year-olds reject two forms of inequity. Cognition, 120(2), 215-224.

Campbell, T. (1988). Justice. Edt: Jones, P., Weale, A. Macmillan Education.

Çeçen, A. (2020). Adalet kavramı. 5.Basım, Ankara, Astana Yayınları.

Demirtaş, M. (2016). Antik Yunan filozoflarındaki adalet anlayışının İslam filozoflarına etkisi. Uluslararası Sosyal Araştırmalar Dergisi, 9(43), 2435-2449.

Dworkin, R. (1986). Law's empire. ISBN 9780674518360, Chambridge, Massachusetts, The Belknap Press of Harward Univercity Press.

Elenbaas, L., Rizzo, M.T., Cooley, S. \& Rackozyv, M.K. (2016). Rectifying social inequalities in a resource allocation task. Cognition, 155, 176-187.

Enesco, C.S. \& Warneken, F. (2015). The shadow of the future: 5-years olds but not -3 years olds- adjust their sharing in antispation of reciprocation. Journal of Experimental Child Psychology, 129, 40-54.

Esteban, M.E.P. (2005). Los conceptos de justicia y derecho en Kant. Kelsen, Hart, Rawls, Habermas, Dworkin y Alexy, Retriwed from https://revistascolaboracion.juridicas.unam.mx/index.php/juridica/article/view/11597/10608.

Fehr, E., Bernhard, H. \& Rockenbach, B. (2008).Egalitarianism in young children. Nature, 454, 1079-1083.

Gummerum, M. \& Chu, M.T. (2014). Outcomes and intentions in children's, adolescents and adults second- and third-party punishment behavior. Cognition, 133, 97-103.

Halıcı, A.H. \& Van, N. (2016). Ortaokullarda okutulan "hukuk ve adalet" dersinin öğrenciler üzerinde hukuka yönelik duyuşsal eğilimler algısına etkisi. The Journal of Europe-Middle East Social Science Studies, 2(1), 107-131.

Hart, H.L.A. (2012). The concept of law. (Edt: Bulloch, P.A, Raz, J). Clarendon Law Series, ISBN: 9780199644698, Oxford Universty Press.

Kristja'nsson, K. (2004). Empathy, sympathy, justice and the child. Journal of Moral Education, 33(3), 291-305.

LoBue, V., Nishida, T., Chiong, C., DeLoache, J.S. \& Haidt, J. (2011). When getting something good is bad: even three-year-olds react to inequality. Social Development, 20(1), 154-170.

Moore, C. (2009). Fairness in children's resource allocation depends on recipient. Pyschological Sciense, 20(8), 944-948.

Murnighan, K. \& Saxon, M.S. (1998). Ultimatom bargaining by children and adults. Journal of Economic Psychology, 19(4), 415-445. 
Rakoczy, H., Kaufmann, M. \& Lohse, K. (2016).Young children understand the normative force of standarts of equal resource distribution. Journal of Experimental Child Psychology, 150, 396403.

Rawls, L. (1973). Theory of justice. The Journal of Phylosophy, 70(9), 245-263.

Riedl, K., Jensen, K., Call, J. \& Tomasello, M. (2015). Restorative justice in children. Current Biology, 25, 1731-1735.

Shaw, A. \& Olson, K. (2014). Fairness as partiality aversion: The development of procedural justice. Journal of Experimental Child Psychology, 119, 40-53.

Takagishi, H., Kameshima, S., Schug, J., Koizumi, M. \& Yamagishi T. (2010). Theory of mind enhances preference for fairness. Journal of Experimental Child Psychology, 105(1-2), 130-137.

Yazıcıoğlu, Y. \& Erdoğan, S. (2004). SPSS uygulamalı bilimsel araştırma yöntemleri, Detay Yayıncilik, Ankara. 